\title{
レーヨンの繰り返し定伸張
}

\author{
東京工業大学 白樫 侨 - 宮坂啓象 - 石川欣造
}

\section{THE CYCLIC EXTENSION OF RAYON AT CONSTANT STRAIN}

\author{
By Kan Shirakashi, Keizō Miyasaka and Kinzō Ishikawa
}

(Tokyo Institute of Technology, Ookayama, Meguro-ku, Tokyo, Japan)

The cyclic extension of ordinary and high tenacity rayon at constant strain have been studied at various conditions (constant strain : $3 \sim 7 \%$, frequency of extension $: 3 \sim \frac{1}{2} c / s$ ) on the following aspects:

1) The real amplitude of the stress and strain during cyclic extension at constant strain.

2) The mechanical properties of the cyclically strained rayon.

3) The change in length of the cyclically strained rayon in water.

4) The variation of the lateral order distribution at the low region of aggregation.

The results on the above tests show that when rayon is given cylic extension at constant strain, the structure is monotonically strengthened and the change in structure recovers perfectly in water when the constant strain is less than $5 \%$ (ordinary viscose rayon) and $7 \%$ (high tenacity rayon). The lateral order distribution at the low region of aggregation which may be relaxed by water vapour shows that the change in structure of cyclically strained rayon corresponds to the decrease of the very low order region corresponding to about $10 \sim 50 \% \mathrm{RH}$ and the increase of the region corresponding to more than $60 \% \mathrm{RH}$.

(Received September 19, 1961)

\section{緒言}

動的な伸張疲労作用には種々のタイプがある゙。われ われはその中の基本的なタイプの一つである繰り迈し定 伸張をレーヨンに与え種々の穾験を行なった。

この種の伸張作用についての一般的な解説 2 は，2，3 あるが詳細比ついての報告はほとえどない。それ性寒用 上工業的な面ではこの種の疲労作用を絾維の受ける場合 が比較的少ないことによるものと考党られる。

しかしながら製織中にタテ糸のヨコ打らの際に受ける 伸張とか衣料用縂維としては人体の関節部に接する部分 (例えば，ひし，ひさなど）の受ける伸張作用も基本的 には，この種の伸張疲学作用に類似すると考えられる。

このよ5な実用的與味をともにわれわれがこの種の疲 労作用を対象としたのは，乙の作用が他の種のものに対 して比較的弱く痩労切断が起こり難いため疲労現象を材 料の構造变化またはとれにもとつく物性の変化とい5面 から追求することが容易なためである。すなわら他の種 の疲労作用では比較的早期に切断を生し，ての疲労過程 を全般的な構造变化から追求することが困難な場合が多 wo
本研究に和いては，定伸張繰り返し作用によつてレー ヨンがいかなる構造の变化を示すかに注目し，間接的に は機械的特性の変化から，また直接的には内部凝集状態 の変化を追求し、レーヨンの定伸張繰り返し作用の本質 を明らがすることを目的とした。

\section{実験結果および考察}

レーヨン試料は市販の普通ビスコースレーヨン系(120

d) 扰よ゙゙スーパータイブのタイヤコード原系(1650d) でいふれる僅かの撚がかけられている。

案験保，

(1) 定伸張繰り返し中の伸張振偪，応力振幅

（2）定伸張繰り返しを与えたレーヨン試料の（i)機 械的特性，(ii)水中膨潤，收縮举動，(iii)凝集オーダー の分布の決定よりなつている。

定伸張繰り返し装置の概要を Fig. 1 に示す。

この装琶を用い定伸張率を3〜7\%（槊通レーヨンの み $10 \%$ まで) の範团で変化させ，また伸張周波数を $\frac{1}{2} \mathrm{c} / \mathrm{s} \sim 3 \mathrm{c} / \mathrm{s}$ の範团で变化させた。実駼は，すべて $20^{\circ} \mathrm{C}$ $65 \%$ RH で行なつた。 


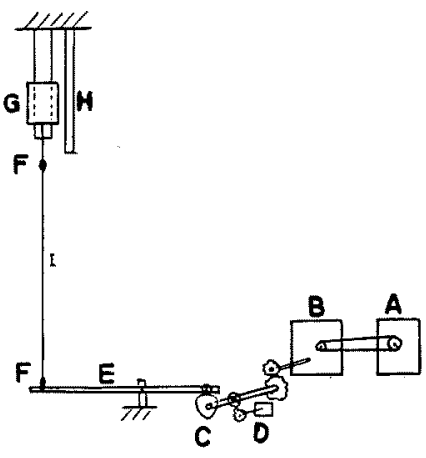

Fig. 1. Diagram of the apparatus of cyclic con. stant strain extension. A; motor B ; speed controller $\mathrm{C}$; cam $\mathrm{D}$; cycle recorder $E$; connecting rod $F$; sample grips $\mathrm{G}$; strain-gauge $\mathrm{H}$; scale I ; sample

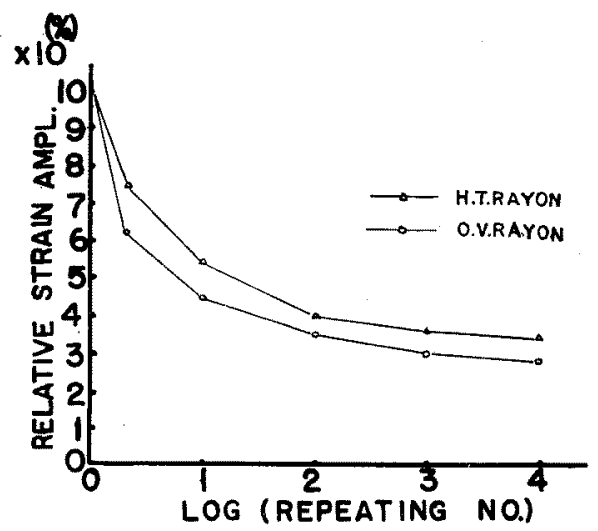

Fig. 2. Relative changes of real strain amplitude during cyclic extension at constant strain.

（1）定伸張繰り返し中の伸張振幅, 応力振幅の变化

(i) 伸張振幅の变化

伸張繰り返しによってンーヨンは残留ひすみを生じ， 実際に応力が現わ札る伸張振輻は次第に要化して行く。 結果を Fig. 2 《示す。

定伸張繰り返しの条件在変えた場合についても結果は ほとんど同じ傾向を示すため以後全て定伸張率 $5 \%$ ，伸 張周波数 $3 \mathrm{c} / \mathrm{s}$ についてのみ示寸。

Fig.2 の女テ軸怯，第 1 回目の伸張に括ける伸張振幅 (定伸張率) を100とした各伸張繰り返し数における相 対值を, ヨコ軸は伸張繰り返し数の対数を示す。初期に 扣いて件張振幅が急激儿減少し，定伸張繰り返し条件を 变えた場合，定伸張率が大きい程，また伸張周期が長い 程伸張振㨽の低下が著しい。
両レーヨンを比較すると強力レーヨンの方が，同一の 定伸張綵り返し采件の下では常に伸張振幅は大きい。こ れは，後者の構造が安定であり流動が起こり難いためで ある。

(ii) 応力振膘の变化

定伸張繰り返し作用は，不潓絸な応力緩和現象である ため時間（または伸張繰り返し数）の経過につれて汒力 振幅が低下して行く。結果をFig.3 火示す。

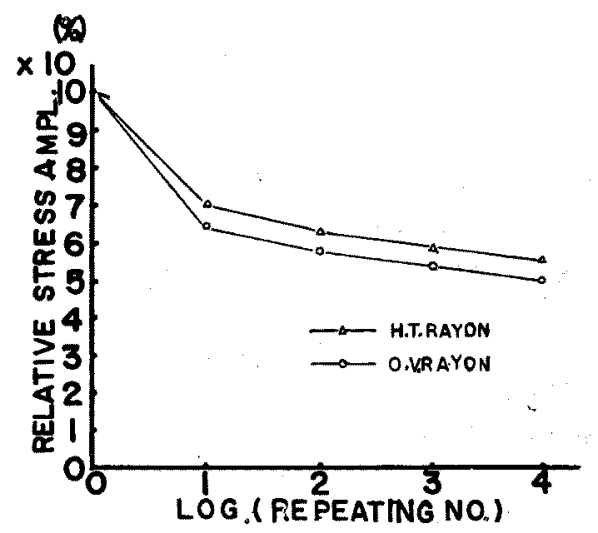

Fig.3. Relative changes of stress amplitude during cyclic extension at constant strain.

Fig. 3 のタテ軸は第 1 回目の伸張の際に現わ机る応力 振幅を100とした各伸張繰り返し数における相対值を， ヨコ軸は伸張繰り返し数の対数を示す。この場合にも初 期比扣いて低下が著しく一般に，定伸張率が高い程，ま た伸張周期が短い程，応力振幅の低下は大きい。

両レーヨンの相違は娄り明らかでない。なお第 1 回 目の伸張に括壮る応力振幅と伸張周波数の関俰は, 伸張 速度の対数と応力が一次的な関係を持つという Mere-

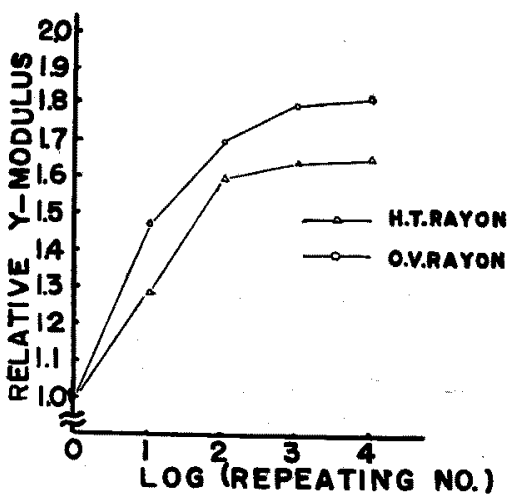

Fig. 4. Relative changes of Young's modules during cyclic extension at constant strain . 
dith の記述を満足した。

以上の伸張振幅就よび応力振幅から定伸張綝り返し中 の劝けのヤング率の变化を求めると Fig. 4 になる。

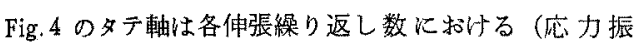
幅/伸張振幅) の值の第 1 回目の件張に和讨るその值を 100 とした相対値を、ヨコ軸は定伸張繰り返し数の対数 を示寸。

雨レーヨンとも伸張繰り返し初期比いて著しくみか

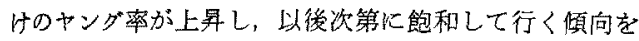
示している。

（2）定伸㲀綝り返しを受けたレーヨンの機械的特性 (i) 切断強伸度

所定数の定伸張繰り返しを与えたレーヨンの切断強伸 度をインストロン型抗張力試駼機で測定した。伸張速度

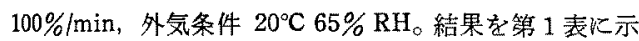
す。以下の結果は全て $5 \%$ ，3 c/skついてのものである。

第 1 表 切断强伸度

\begin{tabular}{|c|c|c|c|c|c|c|}
\hline \multirow{2}{*}{ 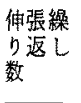 } & \multicolumn{3}{|c|}{ 切断強度 $(\mathrm{g} / \mathrm{d})$} & \multicolumn{3}{|c|}{ 切断伸度 $(\%)$} \\
\hline & \multicolumn{2}{|c|}{$\begin{array}{l}\text { 通 } \\
V-\Xi y\end{array}$} & 強ーヨン & \multicolumn{3}{|c|}{ 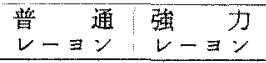 } \\
\hline & 空中 & 水中 & 空中 水中 & 空中 & 水中 & 空中 水中 \\
\hline 0 & 1.82 & 0.83 & 3. $48 \quad 2.62$ & 19.1 & 27. & $12.5 \quad 23.0$ \\
\hline 1 & 1.84 & 0.84 & $3.45 \quad 2.63$ & 18.5 & 27.2 & 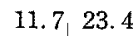 \\
\hline 100 & 1.88 & 0.83 & 3.442 .60 & 16.3 & 27.3 & 10.423 .3 \\
\hline 1000 & 1.84 & 0.82 & 3.442 .60 & 14.9 & 27.2 & 9.023 .3 \\
\hline
\end{tabular}

第1表によると切断強度はほとんど变化しない。この よろな結果は，加熱などの物理化学的な作用をとるなる 效い，伸裴疲労作用の場合によくみられるものであるれ。

以上の結果から，定伸張䍃り返しによってレーヨンの 切断強度を担了強力な骨格構浩には、注とんど変化を受 けないと推定される。水中に捕汁る切断強度について も，同樣な結果がみられた。

一方切断伸度は，及かけ上次第に 減少して行く。先机らの各々の值 に, 定伸張繰り返しによつて生じて いる残留ひず量を加光た值も定伸 張繰り返しを与克ない試料の切断伸 度より小さく，次第汇減少して行 く。

(ii) 抗張力エネルギー，長さの 弾性度, 仕事の弾性度

定伸張繰り返しを与えた試料代っ いて上の三つの特性值を求めた。結 果住伸張速度 $100 \% / \mathrm{min}$ 伸張率 $5 \%$ についてのものである。外気条件は
第 2 表 抗張力ェネルギ一, 長さの弹性度, 仕事の 弹性度

\begin{tabular}{|c|c|c|c|c|c|c|}
\hline \multirow{2}{*}{$\begin{array}{l}\text { 伸張絽 } \\
\eta \text { 返 } \\
\text { 数 }\end{array}$} & \multicolumn{2}{|c|}{$\begin{array}{l}\text { 抗張才エネルギ } \\
-\quad(\mathrm{g} \cdot \mathrm{cm} / \mathrm{d})\end{array}$} & \multicolumn{2}{|c|}{$\begin{array}{c}\text { 長さの弾性度 } \\
(\%)\end{array}$} & \multicolumn{2}{|c|}{$\begin{array}{c}\text { 仕事の弾性度 } \\
(\%)\end{array}$} \\
\hline & $\begin{array}{l}\text { 普通レ } \\
-\Xi ン\end{array}$ & $\begin{array}{l}\text { 強力レ } \\
-\exists ン\end{array}$ & $\begin{array}{l}\text { 普通 } 2 \\
-\Xi y\end{array}$ & $\begin{array}{l}\text { 強力口 } \\
-\Xi y\end{array}$ & $\begin{array}{l}\text { 普通V } \\
\text { ーョン }\end{array}$ & $\begin{array}{l}\text { 強力レ } \\
=\Xi 2\end{array}$ \\
\hline 0 & 0.38 & 0.45 & 42.5 & 55.8 & 21. 2 & 32.7 \\
\hline 1 & 0.40 & 0.47 & 44.6 & 57.9 & 24.5 & 38.0 \\
\hline 100 & 0.48 & 0.56 & 51.4 & 67.9 & 26.7 & 46.1 \\
\hline 1000 & 0.53 & 0.61 & 54.8 & 75.8 & 27.0 & 48.0 \\
\hline
\end{tabular}

$20^{\circ} \mathrm{C} ， 65 \% \mathrm{RH}$ である。結果を第 2 表に示す。

第 2 表に上れば，上の三つの特性值とも定伸張繰り返 しが進む沉っれて単調汇增加して行く。すなわち、レー ヨンは, 抗張性の高いしかる, 弾性汇富む構造に変化し て行く。普通レーヨンと強カレーヨンの間の相異はあま り明瞭でない。一般に定伸張率の大きい程, 上記特性値 の增加は著しい。

(iii) 動的特性檤の変化

定伸張繰り返しを与えた試料の動的特性值を直読方式 で測定した。結果を第3表に示す。測定は $20^{\circ} \mathrm{C} ， 65 \%$ $\mathrm{RH}$ 周波数 $106 \mathrm{c} / \mathrm{s}$ で行なつた。第 3 表に上机ば, 動的 弾性率 $\mathrm{E}^{\prime}$ は，両レーヨンと定伸張綵り返しにより次 第に大きな值をとることがわかる。その場合普通レーヨ ンでは比較的単調に增加する。一方強カレーヨンでは初 期で著しく增加を示すが，早く飽和に達する。

この $\mathrm{E}^{\prime}$ の变化々 Fig. 4 亿示された定伸張繰り返し 中の及かけの弾性率の变化とを対比すれば耐者は変形量, 周波数の点から同じ内容を持つものではないが，かなり よく似た傾向を示している。

$\tan \delta$ は，両レーシンとも明瞭な减少を示す。動的損 失 $\mathrm{E}^{\prime \prime}$ は, 両レーヨンとも多少減少の攧向を示す。

以上の動的特性值の変化の倾向は, 先に示した静的な 第 3 表 動 的 特 性 值

\begin{tabular}{|c|c|c|c|c|c|c|}
\hline \multirow{3}{*}{$\begin{array}{l}\text { 伸張繰 } \\
\text { 数返 } \\
\text { 数 }\end{array}$} & \multirow{2}{*}{\multicolumn{2}{|c|}{$\mathrm{E}^{\prime}$}} & \multirow{2}{*}{\multicolumn{2}{|c|}{$\tan \delta$}} & \multirow{2}{*}{\multicolumn{2}{|c|}{$\mathrm{E}^{\prime \prime}$}} \\
\hline & & & & & & \\
\hline & $\mid$\begin{tabular}{|l} 
普 \\
通
\end{tabular} & $\begin{array}{c}\text { 強 } \\
\text { ○一 }\end{array}$ & 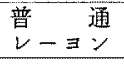 & 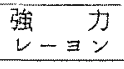 & 普一通 & 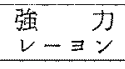 \\
\hline 0 & $8.41 \times 10^{10}$ & $9.76 \times 10^{10}$ & $45 \times 10^{-3}$ & $33 \times 10^{-3}$ & $3.78 \times 10^{9}$ & $3.22 \times 10^{9}$ \\
\hline 1 & 8.67 & 10.21 & 43 & 31 & 3.73 & 3. 22 \\
\hline 100 & 9.07 & 10.42 & 41 & 29 & 3.72 & 3. 02 \\
\hline \multirow[t]{2}{*}{1000} & 9.46 & 10.43 & 39 & 29 & 3. 68 & 3.02 \\
\hline & 〔水 & 中] & & & & \\
\hline 0 & $1.30 \times 10^{9}$ & $7.32 \times 10^{9}$ & $26 \times 10^{-2}$ & $24 \times 10^{-2}$ & $3.40 \times 10^{8}$ & $1.81 \times 10^{9}$ \\
\hline 1. & 1.29 & 7.25 & 26 & 24 & 3.40 & 1.80 \\
\hline 1000 & 1.31 & 7.34 & 26 & 24 & 3. 40 & 1.81 \\
\hline
\end{tabular}




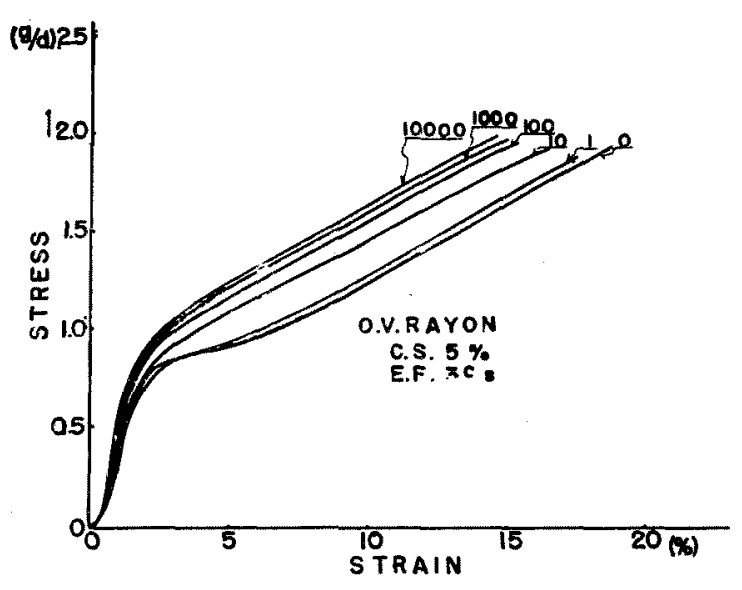

Fig. 5. Stress-strain curves of cycllially strained rayon.
次第に不明瞭になり，(2)定伸張率が大きい時㤃， 降伏項域を過ぎたあとで，低荷重側への屈折がみ られる。

定伸張率方大さい伍ど、をた伸張周期が短い任 ぞ, その荷重〜伸張曲線は高荷重側に移行する。

(2)の屈折点がよく現われる例を Fig.7 に示卞。 Fig.7 にみられるよ5に屈折点は，定体張繰り返 しが進さにつれて，次第に高荷重側に移行して行 く。まこの屈折点以後の曲線の勾配は，定伸張 繰り返しを与えない試料の荷重一伸張曲線上の高 伸張領域の公配と活ぼ一致する。従つて，この屈 折点に到つて，定伸張繰り返しによつて生じた新 しい構造が破壤するすのと推定される。

従つてこの屈折は，定伸張率が高い湯合だけて なく一般にみられるはずでするが，低伸張率の場

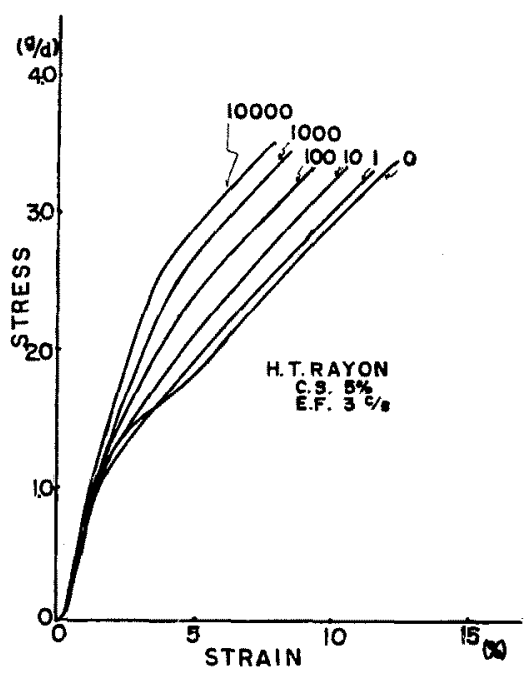

Fig.6. Stress-strain curves of cycllically strained rayon.

結果ともよく一致している。これらの事害は定伸钱繰り 迡しによつて，レーヨンの構造が，次第にb密に，弾性 的なるのに移つて行くことをはつきり示している。この よろな，满造のち密化の問題は分子の配向化，凝集状態 の向上炕起因すると考えられるが，それらの問題につい ては後述する。

(iv) 荷重 伸張曲線

定伸張繰り返しを与克た試料の荷雪〜伸张曲線を $20^{\circ} \mathrm{C}$ $65 \% \mathrm{RH}$ 伸張速度 $100 \% / \mathrm{min}$ で求めた。結果の一部を Fig. 5, Fig.6 に示す。図中の数字は伸張繰り返し数支 表わす。一般的に定伸張繰り返しが進むにつれてとの荷 重一伸張曲線は高荷重側に移行し，その際，降伏点が

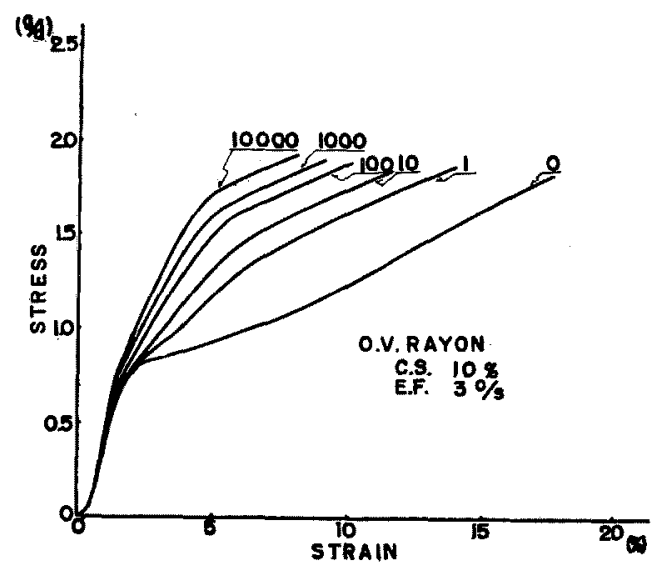

Fig.7. Stress-strain curves of cycllically strained rayon.

台には荷重〜伸張曲線の初期の勾配の增加が小であるた め，不明瞭になるものと考えられる。同一の定伸張率で 伸張周期を变えた場合，周期が短い時は，残留ひずみ量 が小であるにもかかわらず荷重〜伸張姆線は高荷重側に 存在する。定伸張を繰り返し与えることによつてレーヨ ンが、このように，より抗張性を示す原因は，棈造的に みれば伸張を繰り返し与えられることにより，構造内部 の配列化が起こり，また一方に批いて，それに起因する 分子の接近により低い凝集領域に扣いて，二次結合の生 成が行なわれ，凝集样式の向上がみられるためである。 このよ5な分子ないしは搆造単位（結晶を含め）の配列 化の大小が，われわれの観測にかかる残留ひず双の大小 と一応，対応を持つと考文てよいことは複屈折の結果か 認められている。攽つて，上に述べた害験の結果は配向 
化と澄集様式の向上が必ずしす対応しないことを示して いる。この点については，伸張速度を变辛詳絸に検討す 寻予定でする。

一方，緩和機構の面からみれば，定伸張を繰り返し与 えることにより，次策に短い緩和時間を持つ緩和要素が

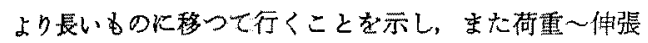
曲線が降伏点以唩で先に方したよ5に屈折を示し，その

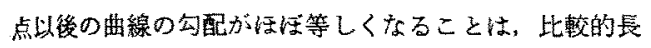
い和和間を持つ緩和要素は，定儌張繰り返しによつて ほとんど影暃を受けないことを示す。この結果，定伸㖘 繰り返しによつてレーヨンの縓和時間の分布の变化は, 比警的短い緩和時間領域においててのみ起をると推定され る。綎和时間の長短を凝集オーダーと対応して考えた場 合には，これらの結果は，定伸張繰り返しによつて骨格

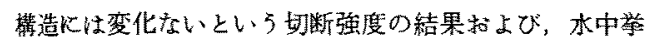
動の結果とるよく一致するものである。

(v) 水中の膨潤，汉樎挙動

一般に定伸張繰り返しを与えたレーヨン残留ひずみ を生し，内部ひす多を包含するため水に漫せさすると， 我で切断され得る凝策領域において結合がが綬和される ため，新たな平衡状態をとり収維する。

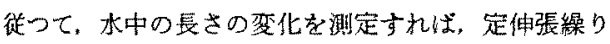
返しによつて生する残留ひすみがとの上うな凝集領域に 扰いて生ずるるのでるるかについてつの目安を得るこ とがでる。しかしこの内部ひするの緩和に基づく收

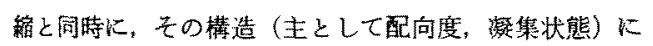
よつて決る膨潤が起きる。このためわれわれの䫏察にか

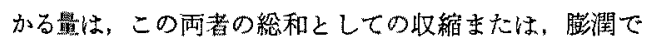
ある。

定伸張絽り派しを与えたレーヨン試粼を，20ㅇの水中

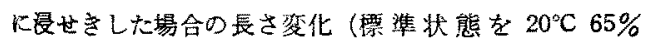
RH に拁ける長さにとる) を測定した。結果をFig.8に

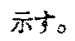

Fig.8によれは，膨潤または収絠量は，両レーヨンを

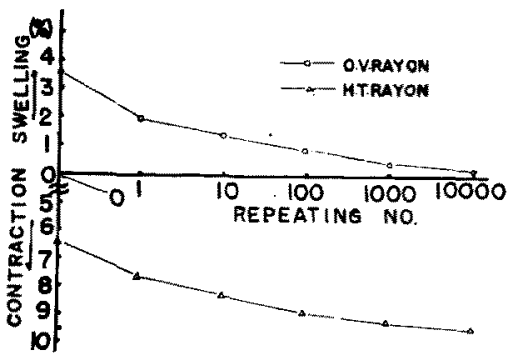

Fig. 8. Change of length in water of cycllically strained rayon.
も定体張繰り返しによつて次第に变化して行く。しかし これらの各タの值に定伸張繰り返しによつて生している

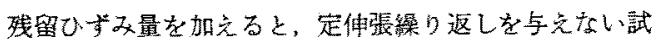
料の值とほば等しくなる。この結果定伸張繰り返しによ つて生ずる残能ひずみは，管温の水に浸让さすることに よって回復する，可逆的な構造変化によるものでない かと推定される。高い定伸張率の場合普通レーヨンで は, 非可逆的な变化が双られるが, それはすでに第回 1 目の体張で現われるるので市つて, 以後の伸張繰り返し

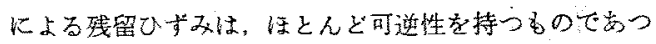
tom

しかし，先に述べたよ5に，われわれの矮察した量は 収維と膨潤の三つに関係する量であるため，残留ひずみ

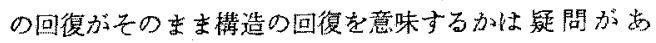

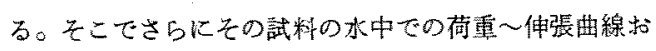
上び動的特性值を求め心結果, 定伸張繰り返しの有艋汇 かか放らす，同一の結果壱不した。従つて，定伸張繰り 返しによつて生ずる構造の変化は，专として，常温の水 中に浸せきすると回復するものであることが，確かめら れた。

（4）凝集オーダー分布の変化

定伸張繰り这しKよつて生ずるレーヨンの構造変化が

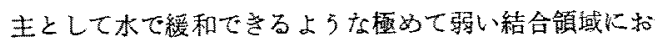
いて起きるものであることがすでに確められた。

いまここで問題としているょうな水で楥和し得る極め。 て低い凝集領域に拝ける凝集オーダーの分布については 前田 ${ }^{5)}$ によ，各相対湿度に扣ける所定の伸張率に至る までの抗張エホルギーから求める方法が提案されてい 当。

本研究に和いてもこの方法を用い定伸張繰り返しを与 えたレーヨンを各相対鼬度 $(10 \%$ 100\%) で伸張し， 5 . \%伸張に要する伸張仕事量を求め，こ机からラテラルオ 一ダーの分布滰求めた。

試料を数時間常温で五酸化噒を用い乾燥した後, 所定 の湿度の空気中に数時間放算して実験した。結果至 Fig. 9 に示す。

Fig.9からら明らかなように，扰上そRH $50 \%$ ，以下 に対底子る領域が，定伸張繰り返しが進比つんて次第 に減少してゆく。强力レーヨンは，これに対して，60\% RH 以上に対応する領域が次第に堌加するのが明瞭にみ

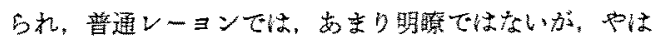
り同様な領域での增加がみられる。定伸張繰り返しは 65\%RH に和いて行なかれたものてあるから，その時 65\% RH 以下に対応する凝集領域では眼心結合が緩和さ れている。徉つて定伸張縝り返しを受け大埸合，この頒 域は流動を起こしやすく，より高い凝集エネルギーを持 

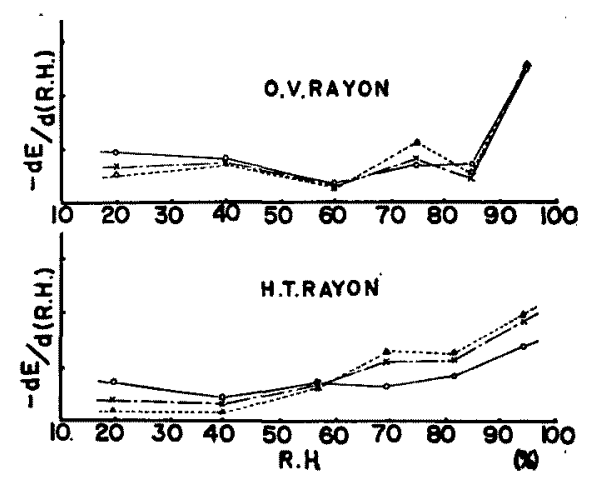

Fig. 9. Changes of lateral-order distribution in the region of low aggregation order of cycllically strained rayon.

$\begin{array}{rr}- & \text { Repeating No. } 0 \\ ---\times- & 100 \\ \cdots \cdots \bigcirc \cdots \cdots & 10,000\end{array}$

つ二次結合形成の可能性は大きいであろ5。このように 考えると約 60\%RHに詨応する㠜集オーダーを中心とし て変化が起きるという本実験の結果の持つ意味も明確に なる。

\section{結論}

レーョンの定伸張䑁り返しについて種々の実験を行な
つた。定伸張繰り返し中の伸張振幅，応力振幅は定伸張 繰り返し条件によつて異なるが一般に伸張絽り返しの初 期に拉いて著しく低下し，以後次第に飽和して行く。 この場合強カレーヨンでは比較的変化が小で, 構造の 安定性を示した。

このような内容の作用を受けたレーヨンの標準状態中 での機械的特性は, 単調に向上した。去の原因は配向化 および凝集オーダーの向上と考光られるが，問題を後者 にしばり検討した。

すなわち，凝集オーダーの変化は，骨格構造比関与す るような高い領域におよばないことを，空中の切断強度 および荷重〜伸張曲線から確め，さらに皮中の機珹的特 性扣上び長さの变化から，水で切断し得る極めて弱い領 域に赫いてのみ，変化が起きること，さらには，水で緩 和される領域のラテラルオーダー分布を求めその変化の 实体を示した。

\section{文献}

1,2) J.H. Dillon; Advanced Colloid Science, Vol. III.

3) Meredith ; The Mechanical Properties of Textile Fibers, 77

4) 白鍴, 石川; 絾学誌，16,392(1956)

5) 前田; 第四回東京化緛研究会講演（昭 33.5.15） 